DOI: $10.15838 / \mathrm{esc} / 2016.1 .43 .9$

UDC 331.101.26(470), LBC 65.240(2Rus)

(C) Leonidova G.V., Svirelkina I.I.

\title{
Non-State Preschool Education: Current Practices of Territorial Development*
}

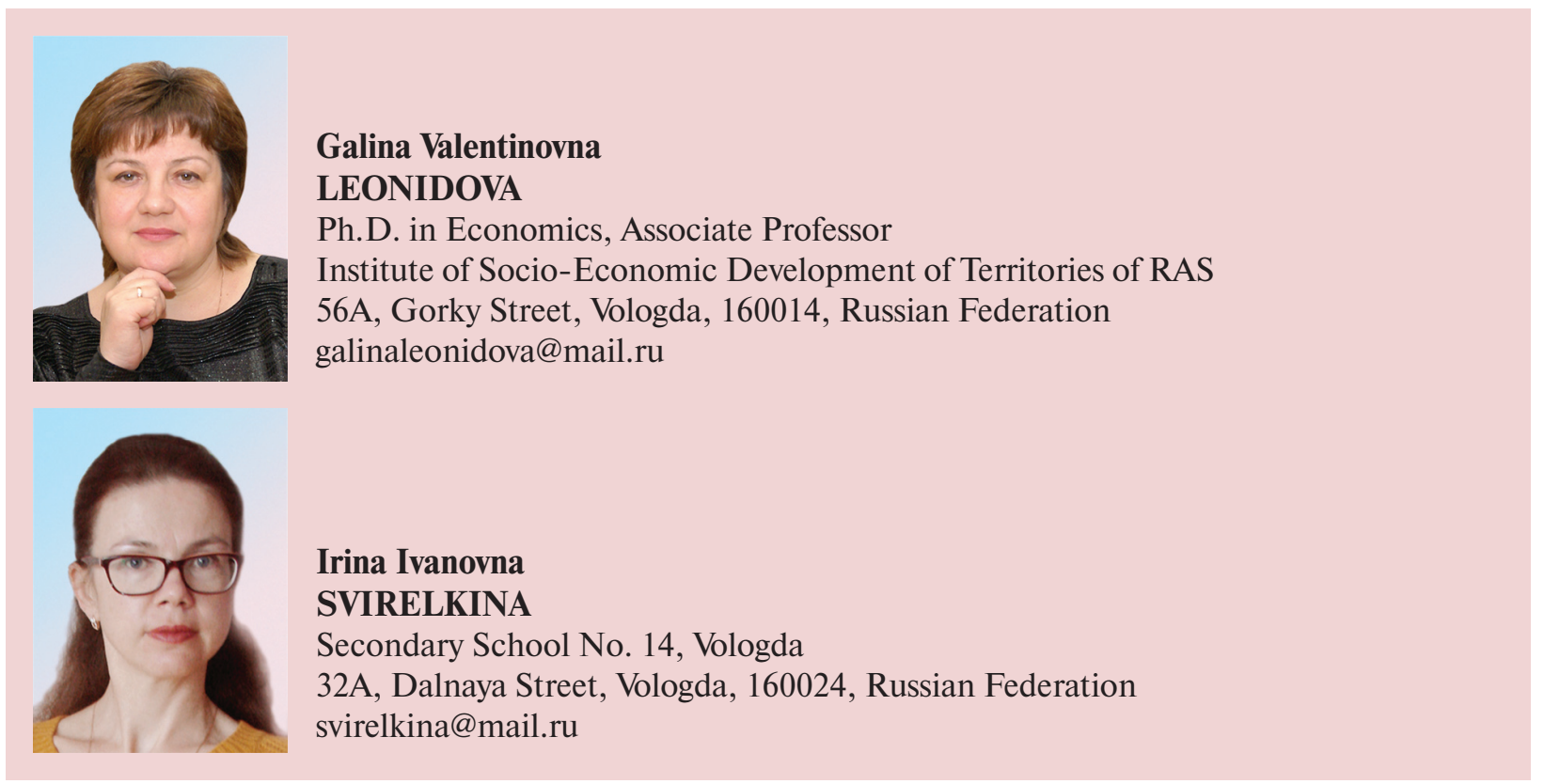

\begin{abstract}
The paper is concerned with the problem of preschool education in Russia and the Vologda region. It shows that in the current context of shortage of places in state nurseries it is necessary to develop private care service providers. Day-care is in great demand among parents having children aged 1-3. The article analyses the main characteristics of preschool educational organizations. It shows that in the Vologda Oblast, particularly in Vologda, private demand for preschool education service is unsatisfied to a wide extent. In Vologda more than ten thousand children are on waiting lists for preschool educational organizations. In total, in the Vologda Oblast about 28.9 thousand children are in line for admitting to a kindergarten, $34 \%$ of them are registered in Vologda. The paper provides the results of the study into Vologda private nurseries and day-care carried out in May-June 2015 by method of involved observation.
\end{abstract}

* The study is performed under support of Russian Foundation for Humanities, project no 15-02-00482 "Socio-cultural determinants of modernization development of Russia: methods of measurement and analysis of causal dependencies (2015-2016)". 
It reveals the key factors hampering growth of private nurseries. It indicates the lack of license of educational activities and motivation of most entrepreneurs to obtain it as one of the factors. The results show that unlicensed gardens are not controlled by the authorities and public organizations. Interaction between the private institutions of pre-school education is not provided as well. We can observe that some private sector organizations do not meet the requirement of health and safety standards and impose limiting measures for the sake of children health such as organization of walks due to the absence of a secure walking site. High amount of parental fee is also found out. The article offers directions for the development of private preschool education service.

Key words: preschool education, accessibility, non-public area, private nursery, day-care.

Ensuring accessibility of preschool education is one of the most important tasks, which solution does not only affect the education system itself, but also the socioeconomic situation in the country, contributing to the employment of families with young children, thereby increasing their welfare. The main targets of preschool education in the medium term are defined in the RF President Decree "On measures on state policy implementation in the field of education and research" No. 599 of May 7, 2012 (achievement of 100\% accessibility of preschool education for children aged 3-7 to 2016) and the National strategy of actions in the interests of children for 2012-2017². The main expected results of the Strategy realization are the following: provision of general availability of preschool education for all categories of children, increase in the flexibility and diversity of forms of pre-school services through the implementation of existing and additional forms of their financing and organization, etc.

1 O Natsional'noi strategii deistvii $v$ interesakh detei na 2012-2017 gody: Ukaz Prezidenta RF ot 1 iyunya $2012 \mathrm{~g}$. № 761 [On the National Strategy of Actions in the Interests of Children for 2012-2017: RF President Decree of June 1, 2012 No. 761]. Available at: http://base.garant.ru/70183566/
According to the Federal State Statistics Service of the Russian Federation, the total number of children registered in pre-school educational institutions amounted to 2.7 million people in 2013 . That is by $13 \%$ more than in 2012 and by 2.8 times more than in $2005^{2}$.

However, families' requirements in preschool education for children aged 18 months are more relevant and significant. When a child reaches this age, the payment of state benefits is terminated ${ }^{3}$ and, accordingly, parents want to go to work: it is especially important for singleparent families ${ }^{4}$. However, the public sector of preschool education for children of this age does not guarantee a place in kindergarten. The task to provide the consumer market with the services, such as supervision and care for toddlers, their development and education, could be fulfilled by the private sector. The

2 Federal'naya sluzhba gosudarstvennoi statistiki [Federal State Statistic Service of the Russian Federation]. Available at: http://www.gks.ru/.

3 This is the monthly benefit (40\% of the average wage) to care for a child up to 18 months.

${ }^{4}$ Kalachikova O.N., Shabunova A.A. Reproduktivnoe povedenie kak faktor vosproiz-vodstva naseleniya: tendentsii $i$ perspektivy: monografiya [Reproductive Behavior as a Factor in the Reproduction of Population: Trends and Prospects : Monograph]. Vologda : ISERT RAN, 2015. 172 p. 
study of the state and problems of private enterprise development in preschool education is the purpose of this article.

All trends in preschool education of Russia in the period from 1991 to 2015 are based on the changes in socio-economic life of the country (tab. 1).

In 1990-2013 the number of kindergartens in Russia decreased twofold (from 88 to 43 thousand units). This happened due to baby bust, closing of kindergartens and transfer of facilities either to primary schools, or commercial structures. In the 1990s the outflow of children from pre-school facilities was associated with financial problems as well (someone could not pay for them, someone hired a babysitter) [22, p. 18]. The analysis of the given data (tab. 2) shows that during the period of economic transformations in the social sphere (the 1990s - the beginning of 21st century) and in modern conditions (20102015) the system of preschool education experienced and continues to experience tensions.

Today, one pre-school organization in the country accounts for by $24 \%$ of children more than in 2010 (148 pupils in 2013 versus 119 in 2010) and almost by 1.5 times more than

Table 1. Features of preschool education sphere development in Russia

in the post-reform period (1990-2015)

\begin{tabular}{|l|l|}
\hline \multicolumn{1}{|c|}{ Period } & \multicolumn{1}{c|}{ Trends and features of the period } \\
\hline Early 1990s & $\begin{array}{l}\text { Maximum number of kindergartens during this period (about } 88 \text { thousand). } \\
\text { Pre-school education was characterized by departmental affiliation of most institutions that gave advantages in material } \\
\text { resources, etc. } \\
\text { The coverage of preschool services accounted for more than 66\% }\end{array}$ \\
\hline Mid 1990s & $\begin{array}{l}\text { Massive reduction of the network of kindergartens. Four-five thousand organizations were annually closed (reformed, } \\
\text { etc.). It mostly concerned departmental educational institutions, which were transferred to municipalities. } \\
\text { The coverage of children by preschool educational institutions was decreased (55\%) (parents were granted leave to } \\
\text { care for a child under the age of 3, the parent fee grew) }\end{array}$ \\
\hline $\begin{array}{l}\text { Late 1990s - } \\
\text { early 2000s }\end{array}$ & $\begin{array}{l}\text { Gradual recovery from the crisis situation. The PEl network continues to decline, but at a slower rate (in 2002 1,100 } \\
\text { kindergartens were closed). } \\
\text { The coverage of children by preschool education accounted for 56\%; demand of preschool institutions increased, } \\
\text { especially groups for children under 3 years of age }\end{array}$ \\
\hline 2005-2010 & $\begin{array}{l}\text { In preschool education the long decline of contingents came to an end, there was a slight growth in the number of } \\
\text { children attending kindergartens. There was a rise in the coverage of children by preschool educational institutions - } \\
61 \% \text { in 2005 }\end{array}$ \\
\hline 2011 - 2015 & $\begin{array}{l}\text { Emergence of the crisis situation in provision of the child population with pre-school education establishments. In 2013 } \\
\text { the coverage of children by preschool educational institutions amounted to 63\% of the total children of appropriate } \\
\text { age. The demand for preschool education increased dramatically due to the grown birth rate due to, on the one hand, } \\
\text { the entry of representative of the cohort born in the 1980s into reproductive age and, on the other, the state measures } \\
\text { (maternity capital, etc.) }\end{array}$ \\
\hline $\begin{array}{l}\text { Source: compiled by the authors; Chis/o doshkol'nykh obrazovatel'nykh uchrezhdenii [Tumber of preschool educational institutions]. } \\
\text { Available at: http://www.gks.ru/wps/wcm/connect/rosstat_main/rosstat/ru/statistics/population/education/\# (data obrashcheniya:15.10.2015). }\end{array}$
\end{tabular}


Table 2. Number of preschool institutions in the Russian Federation and number of pupils (at the year-end)

\begin{tabular}{|l|c|c|c|c|c|c|c|c|}
\hline \multirow{2}{*}{ Area } & \multicolumn{2}{|c|}{2010} & \multicolumn{2}{c|}{2011} & \multicolumn{2}{c|}{2012} & \multicolumn{2}{c|}{2013} \\
\cline { 2 - 9 } & Urban & Rural & Urban & Rural & Urban & Rural & Urban & Rural \\
\hline $\begin{array}{l}\text { Number of preschool } \\
\text { organizations*, thousand units }\end{array}$ & 26.7 & 18.4 & 26.9 & 18.0 & 26.5 & 17.8 & 25.7 & 17.5 \\
\cline { 2 - 9 } & \multicolumn{2}{|c|}{45.1} & \multicolumn{2}{|c|}{44.9} & \multicolumn{2}{|c|}{44.3} & \multicolumn{2}{|c|}{43.2} \\
\hline $\begin{array}{l}\text { Number of pupils in pre-school institutions, } \\
\text { total, thousand people }\end{array}$ & $4,280.6$ & $1,107.3$ & $4,502.4$ & $1,158.8$ & $4,750.6$ & $1,232.2$ & $5,037.1$ & $1,310.2$ \\
\cline { 2 - 8 } & \multicolumn{2}{|c|}{$5,388.0$} & \multicolumn{2}{|c|}{$5,661.1$} & $5,982.9$ & & $6,347.3$ \\
\hline
\end{tabular}

in 1990. The number of children ${ }^{5}$ per 100 pre-school places in 2013 amounted to 105 people, including 108 in cities and urban-type settlements and 93 in rural areas.

The main factor stimulating the development of private entrepreneurship in this field is the shortage of places in public kindergartens. The promotion of the nonstate preschool education sector is part of the state policy in the sphere of attracting private investment in the education system. In the Annual Address to the Federal Assembly ${ }^{6}$, December 4, 2014, Russian President Vladimir Putin said: "We must eliminate discrimination of the non-governmental sector in the social sphere, remove all its barriers" [20].

Nowadays in Russia there are about 50 thousand public kindergartens and only 1200 private ones. Around 600 kindergartens are

5 Doshkol'nye obrazovatel'nye organizatsii (na konets goda) [Preschool educational organizations (end of year)]. Available at: http://www.gks.ru/wps/wcm/connect/rosstat main/rosstat/ru/statistics/population/education/\# (accessed October 26, 2015).

6 Poslanie Prezidenta RF Federal'nomu Sobraniyu 4 dekabrya $2014 \mathrm{~g}$. [Address of the President of the Russian Federation to the Federal Assembly December 4, 2014]. Available at: http://kremlin.ru registered as non-profit organizations ${ }^{7}$. The share of private kindergartens accounts only for $1.3 \%$ of the total number of kindergartens. Moreover, $66 \%$ of all private kindergartens are concentrated in 8 RF regions, with Moscow, the Samara Oblast and the Omsk Oblast being the leaders. According to target indicators of the "road map" (action plan) "Support of the access of non-state organizations to the provision of services in the social sphere", prepared by the Agency for Strategic Initiatives of Russia, non-state preschool organizations are to provide children aged 12 months7 years with education: by $2016-8 \%$ of children, by $2018-15 \%$.

Today, according to the Minister of Education and Science Dmitry Livanov, the share of private licensed kindergartens is significantly higher than the national average (1.8\%) in such RF subjects, as the Sakha (Yakutia) Republic - 4.5\%, Primorsky Krai $-3.1 \%$, Khabarovsk Krai $-3.5 \%$, the

7 In Russia there will be a certificate of a preschooler, which will allow parents to send their children to a private kindergarten at state expense. Available at: http://www.asi.ru/news/25079/?sphrase _id $=784289$ 
Sverdlovsk Oblast $-5.5 \%$, Yamalo-Nenets Autonomous Okrug - 6.2\%, the Republic of Karelia $-4.4 \%$, the Irkutsk Oblast - by $3.0 \%$, Krasnoyarsk Krai $-3.0 \%$, and Moscow $-6.3 \%$. At the same time, there are regions that have no non-state kindergartens, such as the Kabardino-Balkar Republic, Kamchatka Krai, and the Tambov Oblast [3, 11].

The study shows that, in general, Russia has formed the legislative basis for the functioning of non-state preschool education establishments of different types and their support on the part of federal and regional authorities. In particular, the rights and responsibilities of individual entrepreneurs are equal to state organizations operating in the sphere of preschool education. The conditions and mechanisms of financial support and tax exemptions for private kindergartens are determined.

The functioning of non-governmental organizations of preschool education is regulated by the federal law "On education in Russian Federation" of December 29, 2012 No. 273-FZ [15].

In 2010 the federal law "On non-commercial organizations" No. 7-FZ included Article 31.1 "Support for socially oriented non-profit organizations by public authorities and bodies of local self-government" [18]. According to this article, organizations, performing activity in the field of education (including preschool), are classified as socially-oriented. It describes forms of their support ensured by the authorities of RF subjects and bodies of local self-government, such as:

- financial, property, informational, consulting support, as well as support in the field of training, retraining, advanced training and additional professional education of employees;

- provision of privileges on payment of taxes and fees;

- placing of orders for execution of goods, performance of works, rendering of services for state and municipal needs in the procedure provided for by the federal law of July 21, 2005 No. 94-FZ;

- guaranteeing legal persons, financially supporting socially oriented non-profit organizations, exemption from taxes and duties in accordance with the law.

The Ministry of Economic Development of Russia assists small and medium enterprises in form of subsidies to the RF subjects [19] (Ministry of Economic Development Order of April 24, 2013 No. 220). The new sanitaryepidemiological requirements to preschool groups, located in apartments and private homes are approved [17, 23].

May 3, 2015 the Russian President signed the law, stipulating that private day care organizations for early childhood education are exempt from profit tax [13]. Such organizations are entitled to the zero tax rate on profit. The new rule concerns kindergartens, pre-school and after-school care groups at schools 8 .

Let us consider the formation of the framework for private entrepreneurship in the sphere of preschool education on the example of a specific territory (the Vologda Oblast and Vologda).

8 Markelov R. Sbory ushli v nulevku [Fees Went to Zero]. Available at: http://www.rg.ru/2015/05/05/detsad.html 
Table 3. Key indicators of the preschool organizations functioning in the Vologda Oblast

\begin{tabular}{|c|c|c|c|c|c|c|c|c|c|}
\hline \multirow{2}{*}{ Indicators } & \multicolumn{8}{|c|}{ Year } & \multirow{2}{*}{$\begin{array}{l}2014 \text { to } \\
2000, \%\end{array}$} \\
\hline & 2000 & 2008 & 2009 & 2010 & 2011 & 2012 & 2013 & 2014 & \\
\hline Number of preschool organizations & 683 & 624 & 617 & 600 & 598 & 577 & 560 & 490 & 71.7 \\
\hline Number of pupils, thousand people & 51.5 & 60.8 & 61.8 & 62.9 & 65.1 & 67.4 & 70.7 & 72.9 & 141.5 \\
\hline Number of children per 100 places & 76 & 103 & 104 & 106 & 103 & 101 & 102 & 104 & 136.8 \\
\hline
\end{tabular}

Sources: Detskie doshkol'nye uchrezhdeniya v Vologodskoi oblasti v 2004-2008 godakh : stat. sb. [Preschool Institutions in the Vologda Oblast in 2004-2008 : Statistics Digest]. Vologdastat [Territorial Body of the Federal State Statistic Service in the Vologda Oblast]. Vologda, 2009. 42 p.; Doshkol'nye obrazovatel'nye organizatsii Vologodskoi oblasti v 2010 - 2014 godakh : stat. sb. [Preschool Institutions in the Vologda Oblast in 2010-2014 : Statistics Digest]. Vologdastat [Territorial Body of the Federal State Statistic Service in the Vologda Oblast]. Vologda, 2015.63 p.

Table 4. Key indicators of the preschool organizations functioning in Vologda

\begin{tabular}{|c|c|c|c|c|c|c|c|c|c|}
\hline \multirow[t]{2}{*}{ Indicators } & \multicolumn{8}{|c|}{ Year } & \multirow{2}{*}{$\begin{array}{l}2014 \text { to } \\
2000, \%\end{array}$} \\
\hline & 2000 & 2008 & 2009 & 2010 & 2011 & 2012 & 2013 & 2014 & \\
\hline Number of preschool organizations & 78 & 82 & 82 & 82 & 83 & 84 & 86 & 85 & 108.9 \\
\hline Number of places & 17,047 & 13,856 & 13,978 & 13,698 & 16,740 & 16,968 & 17,430 & 17,649 & 103.5 \\
\hline Number of pupils & 12,795 & 16,177 & 16,630 & 16,781 & 17,840 & 18,642 & 19,867 & 20,443 & 159.8 \\
\hline Number of children per 100 places & 75 & 117 & 119 & 123 & 107 & 110 & 114 & 116 & 154.7 \\
\hline \multicolumn{10}{|c|}{$\begin{array}{l}\text { Sources: Data of the Federal State Statistics Service of the Russian Federation. Available at: http://www.gks.ru/; Detskie doshkol'nye } \\
\text { uchrezhdeniya v Vologodskoi oblasti v 2004-2008 godakh : stat. sb. [Preschool Institutions in the Vologda Oblast in 2004-2008: Statistics } \\
\text { Digest]. Vologdastat [Territorial Body of the Federal State Statistic Service in the Vologda Oblast]. Vologda, 2009. 42 p.; Doshkol'nye } \\
\text { obrazovatel'nye organizatsii Vologodskoi oblasti v } 2010-2014 \text { godakh : stat. sb. [Preschool Institutions in the Vologda Oblast in } 2010-2014 \text { : } \\
\text { Statistics Digest]. Vologdastat [Territorial Body of the Federal State Statistic Service in the Vologda Oblast]. Vologda, 2015. } 63 \text { p. }\end{array}$} \\
\hline
\end{tabular}

In the Vologda Oblast, as in the whole country, the network of preschool educational organizations gradually reduced in 2000-2014 (tab. 3).

In comparison with 2000 their number decreased from 683 to 490 units, or by $28 \%$. At the same time, the number of pupils in kindergartens rose from 51.5 thousand to 73 thousand, or by $42 \%$. This was reflected at the demand for a pre-school place. In 2000, 100 places accounted for 76 children, in 2014 104. There are 261 pre-school organizations in the region, while the number of pupils exceeds the number of places. According to the 2014 data, the share of children aged 1-6 attending the Vologda Oblast kindergartens amounted to $83 \%$ of the total number of children of this age. This is significantly higher than the average value in the Russian Federation (63.1\%) and the Northwestern Federal District (76\%). The enrolment rates in preschool education increased in 2012 and 2013 by 3 percentage points, despite the reduction in the number of kindergartens. There is an increase in the coverage of children under the age of 3 with preschool education: $33.1 \%$ in 2013 against $30 \%$ in 2012 .

During the study period the number of kindergartens in Vologda grew from 78 to 85 (tab. 4). They include 20,443 pupils. In comparison with 2000 their number increased by 7,648 people, or $60 \%$. At the same time, the number of places in kindergartens grew

\footnotetext{
9 Informatsiya o vypolnenii plana meropriyatii ("dorozhnoi karty") za 1 polugodie 2014 goda [Information on the implementation of the Action Plan (Road Map) for the 1st Half of 2014]. Available at: http://depobr.gov35.ru/
} 
only by $3.5 \%$ : 17,047 places in 2000 against 17,649 in 2014.

Preschool education organizations of the regional center are "overloaded", as the number of their pupils exceeds the number of places: 100 places per 116 pupils (in $2000-$ 75 , respectively). This overcrowding results in the deterioration of children's health. So, in 2014 of $100 \%$ days children did not attend kindergartens $25 \%$ were missed due to illness (tab. 5).
The increasing demand for preschool education is still largely unmet. This is one of the critical social problems today. More than ten thousand young people are registered to get a place at a preschool educational organization. Compared to the previous year's level, the queue increased by $2 \%$, and since 2006 - by 2.8 times ( $a b$. 6). In the Vologda Oblast 28 thousand children wait for a place in a kindergarten, of which $36 \%$ in Vologda.

Table 5. Attendance in pre-school institutions in 2014

\begin{tabular}{|c|c|c|c|c|}
\hline \multirow{2}{*}{ Territory } & \multirow{2}{*}{$\begin{array}{l}\text { Total attendance, } \\
\text { days }\end{array}$} & \multirow{2}{*}{$\begin{array}{l}\text { Missed, } \\
\text { days }\end{array}$} & \multicolumn{2}{|c|}{ Including } \\
\hline & & & Due to illness & For different reason \\
\hline Vologda Oblast & $12,748,927$ & $4,805,048$ & $1,218,901$ & $3,586,147$ \\
\hline Vologda & $3,726,661$ & $1,442,078$ & 365,868 & $1,076,210$ \\
\hline
\end{tabular}

Table 6. Indicators of provision with places in preschool educational institutions of the Vologda Oblast and Vologda, people

\begin{tabular}{|c|c|c|c|c|c|c|c|c|c|c|}
\hline \multirow{2}{*}{ Indicators of provision } & \multicolumn{9}{|c|}{ Year } & \multirow{2}{*}{$\begin{array}{l}2014 \text { to } \\
2013, \%\end{array}$} \\
\hline & 2006 & 2007 & 2008 & 2009 & 2010 & 2011 & 2012 & 2013 & 2014 & \\
\hline \multicolumn{11}{|c|}{ Vologda } \\
\hline $\begin{array}{l}\text { Number of children registered to get } \\
\text { a place in pre-school organizations } \\
\text { (people) }\end{array}$ & 3,640 & 4,264 & 4,872 & 4,851 & 4,994 & 8,044 & 9,084 & 9,828 & 10,054 & 102.2 \\
\hline $\begin{array}{l}\text { Number of children who got a place } \\
\text { in pre-school organizations, people }\end{array}$ & 2,633 & 2,409 & 2,968 & 3,559 & 3,909 & 4,365 & 4,218 & 4,778 & 3,942 & 82.5 \\
\hline Difference, people & 1,007 & 1,855 & 1,904 & 1,292 & 1,085 & 3,679 & 4,866 & 5,050 & 6,112 & 121.0 \\
\hline \multicolumn{11}{|c|}{ Vologda Oblast } \\
\hline $\begin{array}{l}\text { Number of children registered to get } \\
\text { a place in pre-school organizations } \\
\text { (people) }\end{array}$ & 7,500 & 11,965 & 14,521 & 14,545 & 15,724 & 19,087 & 19,929 & 28,927 & 27,736 & 95.8 \\
\hline $\begin{array}{l}\text { Number of children who got a place } \\
\text { in pre-school organizations, people }\end{array}$ & - & - & 12,083 & 13,750 & 14,036 & 14,785 & 15,469 & 17,172 & 16,084 & 93.6 \\
\hline Difference, people & - & - & 2,438 & 795 & 1,688 & 4,302 & 4,523 & 11,755 & 11,652 & 99.1 \\
\hline \multicolumn{11}{|c|}{$\begin{array}{l}\text { Sources: Detskie doshkol'nye uchrezhdeniya v Vologodskoi oblasti v 2004-2008 godakh : stat. sb. [Preschool Institutions in the Vologda } \\
\text { Oblast in 2004-2008: Statistics Digest]. Vologdastat [Territorial Body of the Federal State Statistic Service in the Vologda Oblast]. Vologda, } \\
\text { 2009. } 42 \text { p.; Doshkol'nye obrazovatel'nye organizatsii Vologodskoi oblasti v } 2010-2014 \text { godakh : stat. sb. [Preschool Institutions in the } \\
\text { Vologda Oblast in } 2010-2014 \text { : Statistics Digest]. Vologdastat [Territorial Body of the Federal State Statistic Service in the Vologda Oblast]. } \\
\text { Vologda, 2015. } 63 \text { p. }\end{array}$} \\
\hline
\end{tabular}


Table 7. Forecast of the number of children aged 0-3 in Vologda for 2015-2023, people*

\begin{tabular}{|c|c|c|c|c|c|c|c|c|c|c|}
\hline \multirow{2}{*}{ Age } & \multicolumn{10}{|c|}{ Year } \\
\hline & $2014^{\star *}$ & 2015 & 2016 & 2017 & 2018 & 2019 & 2020 & 2021 & 2022 & 2023 \\
\hline 2 years & 3,947 & 4,308 & 4,240 & 4,190 & 4,147 & 4,110 & 4,087 & 4,076 & 4,063 & 4,041 \\
\hline 3 years & 3,826 & 3,946 & 4,307 & 4,239 & 4,189 & 4,145 & 4,108 & 4,086 & 4,075 & 4,061 \\
\hline
\end{tabular}

In the regional capital, according to the results of the inertial forecast for the medium term, implying the permanence of sex-age fertility and mortality rates, the number of two-year and three-year-olds will not reduce in the coming years ( $t a b .7)$. The peak growth of children aged 3 will be in 2016; compared to 2014 the number of this population group will increase by $13 \%$ (4,307 children). In 2023 it will be by $6 \%$ more than in $2014(4,041$ children). Nowadays (2015) we observe the peak of growth in the number of children aged 2 - which is by $9 \%$ more than in the previous year. In 2014-2023 the number of two-year old children will grow from 3,947 to 4,041 , or by $2 \%$.

The forecast data indicate that in the near future the load on the municipal network of preschool education will increase. Taking into account the growth in the number of two-yearolds and the unceasing demand for preschool education services for this category of citizens, we should emphasize that the problem of accessibility of pre-school education will remain relevant [9].

The regional authorities have recently adopted a series of documents that define measures to support the non-state sector of preschool education in the Vologda Oblast, in particular the Procedure for determining the amount and paying subsidies for the provision of pre-school education in private educational institutions (the Vologda Oblast Government decree of March 3, 2014 No. 169). In accordance with this document, private pre-school educational institutions having the license for realization of educational activity get subsidies for salaries, purchase of textbooks, teaching AIDS, toys (with the exception of expenditure on maintenance of buildings and utilities).

In the Vologda Oblast there are 5 private organizations, having the license for realization of educational activity and guaranteeing the provision of 665 places $^{10}$. In the first half of 2014, 48 individual entrepreneurs and 33 legal entities registered their activity as "Preschool education" according to the all-Russian classification.

Private entrepreneurship in the sphere of preschool education, according to the study, is more characteristic of urban areas. For example, in Vologda there are more than 40 private organizations, including licensed and unlicensed. It is difficult to identify their exact number for a number of reasons. First, the activities of such organizations are very dynamic. Individual entrepreneurs can start

${ }^{10}$ Informatsiya o vypolnenii plana meropriyatii ("dorozhnoi karty") za 1 polugodie 2014 goda [Information on the implementation of the Action Plan (Road Map) for the 1st Half of 2014]. Available at: http://depobr.gov35.ru/ 
and then terminate their business without notification of tax authorities. Second, there is a share of the shadow economy. Only two organizations have licenses ("Kid" and "Sprout" with 9 branches). Other organizations are registered as individual entrepreneurs and fulfill the function of supervision and care of children. Judging by the study results ${ }^{11}$, entrepreneurs providing services of supervision and care of preschool children do not seek to obtain a license for realization of educational activity, as, according to them, "registration is associated with the collection of a large number of documents, and this, in turn, requires a lot of time and effort". Licensing is considered as a major barrier among the managers of non-state child centers and mini-gardens in Moscow, according to the survey [21, p. 86], conducted by the National Research University Higher School of Economics with support of the NGO "Council for Management and Development" and the Department of Social Protection of Moscow"12: "...we call it as supervision, because it is very difficult to get a license". "To get an

${ }^{11}$ In the second quarter of 2015 ISEDT, using the method of participant observation, surveyed 4 private kindergartens and 10 private organizations that provide services of supervision and care for preschool children in Vologda. The method of participant observation involves an informal collection of data, the researcher is interested in, without questionnaire, but with elements of interviews and observations of social phenomenon. The report on the results of participant observation is descriptive and does not assume any global generalizations and exact numbers. In this case, it was "the choice of nursery for a child", the researchers acted as "parents".

${ }^{12}$ Savinskaya O.B. Chastnyi detskii sad v Rossii: obydennye praktiki i perspektivy razvitiya [Private Kindergarten in Russia: Routine Practices and Development Prospects]. Sotsiologicheskie issledovaniya [Sociological Studies], 2014, no.11, pp. 83-90. educational license is very difficult. Because it is very difficult to get a fire license...", the managers of private kindergartens of the city of Taganrog in the Rostov Oblast claim $[1, \text { p. } 102]^{13}$.

Moreover, some leaders of this business, as it became clear during the participant observation in Vologda, do not find it necessary to have a license. The licensed private kindergartens are controlled by the regional authorities. The activities of unlicensed preschools are not monitored, unless there is a formal complaint from neighbors or parents: "There is no communication with authorities, we do not feel either control, or interest in our activities on the part of education authorities. The city government does not have sufficient information on the activities of the private sector of preschool education". The analysis of private institutions of preschool education shows a lack of information about the licensing procedure; thus, these organizations have certain concerns. The municipal and regional authorities interested in the private sector development should support it not only in terms of paperwork, but also provide information about existing possibilities of state support to the non-state sector of preschool education, thereby stimulating individual entrepreneurs take their business to the next level. The conclusion is shared by the HSE researchers (for example, O.B. Savinskaya [21]), who claim the need for "additional campaign that informs mini-organizations

${ }^{13}$ Aleksandrova O.A., Nenakhova Yu.S. Peremeny v doshkol'nom obrazovanii: tuda li idet Rossiya? [Changes in Preschool Education: where the Right Direction Russia is Going To?]. Narodonaselenie [Population], 2015, no. 1, p. 102. 
operating as individual entrepreneurs about new opportunities for rendering educational services without licensing, stipulated in the new law "On education in the Russian Federation" ${ }^{14}$. O.B. Savinskaya also calls to work out a simplified licensing system for organizations that operate as NGOs and provide educational services [21, p. 87].

Nowadays the effective work is impossible without long-term collaboration, combining resources to achieve concrete results and distributing responsibilities and risks between private and public partners. The licensed private kindergartens "Sprout" and "Kid" demonstrate good examples of effective collaboration. "Sprout" got a license in July 2013. At first, the organization consisted of 3 branches, today it is a network of 9 kindergartens located in different districts of Vologda. The rapid development of "Sprout" is influenced by the cooperation with OJSC "Vologda Region Development Corporation" that from the very beginning of the kindergarten functioning stimulates its growth by providing informational, legal and methodological support.

The private kindergarten "Kid" received a license in February 2015. It was created with the assistance of the private educational institution of additional education "Center "Ego" and with the support of the Department of Psychology and Pedagogics of the Vologda State University.

${ }^{14}$ Savinskaya O.B. Chastnyi detskii sad v Rossii: obydennye praktiki i perspektivy razvitiya [Private Kindergarten in Russia: Routine Practices and Development Prospects]. Sotsiologicheskie issledovaniya [Sociological Studies], 2014, no. 11, p. 87.
The child's stay in a licensed private kindergarten costs approximately 9 thousand rubles a month. One of the surveyed kindergartens has a system of discounts for early payment for some (2 to 12) months. In the period of child's adaptation to a kindergarten (1-2 months) parents pay by 2 thousand rubles less.

According to the Russian legislation ${ }^{15}$, citizens whose children attend kindergartens are entitled to compensation. It is return of parent fees paid for attendance at kindergarten. The amount of compensation is fixed in the normative legal acts of RF subjects, but it is not be less than [15]:

- $20 \%$ of the average size of parent payment for supervision and care of children in state and municipal pre-school educational organizations located on the territory of the corresponding RF subject, for the first child;

- $50 \%$ of such payment for the second child;

- $70 \%$ of such payment for the third child and subsequent children.

The resolution of the Vologda Oblast Government ${ }^{16}$ stipulates the average size of

15 Ob obrazovanii v Rossiiskoi Federatsii : Federal'nyi zakon ot 29 dekabrya 2012 g. № 273-FZ, ch.5 st. 65 [On Education in the Russian Federation : Federal Law of December 29, 2012 No. 273-FZ, part 5 article 65]. Konsul'tantPlyus [ConsultantPlus].

${ }^{16} \mathrm{Ob}$ ustanovlenii srednego razmera roditel'skoi platy za prismotr i ukhod za det'mi v munitsipal'nykh obrazovatel'nykh organizatsiyakh, realizuyushchikh obrazovatel'nuyu programmu doshkol'nogo obrazovaniya: Postanovlenie Pravitel'stva Vologodskoi oblasti ot 11 noyabrya 2013 g. №1155 [On Establishment of the Average Size of Parental Fee for Supervision and Care for Children in Municipal Educational Institutions that Implement Educational Program of Preschool Education: Vologda Oblast Government Decree of November 11, 2013 No. 1155]. Konsul'tantPlyus [ConsultantPlus]. 
parent payment for supervision and care of children in state and municipal pre-school educational organizations $-1,450$ rubles. In this regard, the calculation of compensation of part of parental fee to parents of a child attending a licensed private kindergarten is based on the size of this amount. Until recently compulsory tax amounting to $13 \%$ (PIT) has been levied. However, since January 1, 2015 on the initiative of Vologda Oblast deputies this tax has not been collected and, therefore, the amount of returned payment has increased. Moreover, parents are eligible to social tax deduction in the amount that they have paid for education of their child in kindergarten as long as the organization has a license ${ }^{17}$.

The cost of services provided by unlicensed private kindergartens varies from 8,000 to 13,000 rubles per month. On average the parental fee amounts to 10,230 rubles, which is by $14 \%$ higher than in licensed kindergartens. Of 10 unlicensed private kindergartens 3 organizations have fees above average and 3 - below. In most cases there are no specific relations between the cost of services in unlicensed private kindergartens, their location in the city, conditions of placement, facilities, and the number of teachers and children. In the process of pricing some heads do not rely on certain rules of the market and set their fees on the basis of purely personal interests, ambitions, level of aspiration, and social positioning of their business. Some heads of unlicensed private gardens are focused exclusively on families

${ }^{17}$ In accordance with Subparagraph 2 Paragraph 1 Article 219 of the RF Tax Code approved by federal law of July 31, 1998 No. 146-FZ (amended June 8, 2015). with income above average. In some cases the higher cost is justified: scenic area, 3 teachers and 1 junior teacher for a group, 5 meals, modern toys and educational games, weekly inspection by a pediatrician, surveillance cameras. However, some kindergartens set the fees, not corresponding to the quality of services provided, relying on stable demand for places in preschool educational institutions in the city. Currently in the regional capital the private sector of licensed kindergartens provides approximately 165 places, but more than 10 thousand kids are in line for admitting to municipal kindergartens. A simple mathematical calculation can show that there is sufficient demand for child care services rendered by individual entrepreneurs.

Thus, the non-state sector of educational services in the sphere of preschool education is forming in the municipal education system. Its appearance is associated with a significant shortage of places in kindergartens for children up to 3 years. Private kindergartens are more flexible and can better respond to the needs of children and their parents, thereby eliminating the problem of preschool education availability. However, their development is hampered by several factors [14]:

1. Absence of a license for educational activity and motivation of most individual entrepreneurs to receive one.

2. Lack of control over unlicensed gardens on the part of authorities and public organizations.

3. Lack of interaction among private kindergartens.

4. High amount of parent fees. 
Despite the demand for private institutions, their capacity is not revealed enough today.

Effective development of public-private partnership in this sphere requires, on the one hand, reduced administrative burden on private business in the social sphere $[1,4,21]$ and, on the other, strong supervision of the non-state sector of preschool education on the part of regional authorities. It is necessary to define indicative percentage shares of the non-state sector of preschool education in strategic programs, sub-programs of socioeconomic development of territories, and road maps.

The problem to motivate individual entrepreneurs to get a license for supervision and care of children can be solved if the calculation of pensions of non-state organization employees will include pedagogical experience. It possible to back private business in preschool education by creating consulting centers that provide legal services to private entrepreneurs in the sphere of educational activity and considering this sphere during negotiations between the authorities and entrepreneurs, including business rights commissioners (business-ombudsmen).

The implementation of these measures will help rise the share of the non-state sector in preschool education and ensure meeting the targets of the "road map" to improve the efficiency of education.

\section{References}

1. Aleksandrova O.A., Nenakhova Yu.S. Peremeny v doshkol'nom obrazovanii: tuda li idet Rossiya? [Changes in Preschool Education: where the Right Direction Russia is Going To?]. Narodonaselenie [Population], 2015, no. 1, pp. 95-105.

2. Ballaeva E.A. Problemy razvitiya al'ternativnykh form doshkol'nogo obrazovaniya [Problems of Development of Alternative Forms of Preschool Education]. Narodonaselenie [Population], 2013, no. 1, pp. 64-73.

3. Vystuplenie ministra obrazovaniya i nauki Rossiiskoi Federatsii Dmitriya Livanova na I Vserossiiskom s"ezde rabotnikov doshkol'nogo obrazovaniya [Speech of the Minister of Education and Science of the Russian Federation Dmitry Livanov at the 1st All-Russian Congress of Workers of Preschool Education]. Available at: http:// minobrnauki.rf/

4. Gadzhieva L.A. Ob ispol'zovanii vozmozhnostei negosudarstvennogo sektora dlya resheniya problemy dostupnosti doshkol'nogo obrazovaniya [About Using the Private Sector's Possibilities to Solve the Problem of Availability of Preschool Education]. Voprosy gosudarstvennogo i munitsipal'nogo upravleniya [Public Administration Issues], 2012, no. 4, pp. 169-176.

5. Gosudarstvennyi doklad o polozhenii detei i semei, imeyushchikh de-tei, v Rossiiskoi Federatsii v $2013 \mathrm{~g}$. [State Report on the Situation of Children and Families with Children in the Russian Federation in 2013]. Available at: http://www.rosmintrud.ru/.../Doklad_o_polozhenii_detej_za_2013_god.doc

6. Detskie doshkol'nye uchrezhdeniya v Vologodskoi oblasti v 2004-2008 godakh : stat. sb. [Preschool Institutions in the Vologda Oblast in 2004-2008 : Statistics Digest]. Vologdastat [Territorial Body of the Federal State Statistic Service in the Vologda Oblast]. Vologda, 2009. 42 p.

7. Doshkol'nye obrazovatel'nye organizatsii Vologodskoi oblasti v 2010 - 2014 godakh : stat. sb. [Preschool Institutions in the Vologda Oblast in 2010-2014 : Statistics Digest]. Vologdastat [Territorial Body of the Federal State Statistic Service in the Vologda Oblast]. Vologda, 2015. 63 p.

8. Zhilishchnyi kodeks Rossiiskoi Federatsii : Federal'nyi zakon ot 29.12.2004 g. № 188-FZ [Housing Code of the Russian Federation : Federal Law of December 29, 2004 No. 188-FZ]. Konsul'tantPlyus [ConsultantPlus]. 
9. Shabunova A.A., Kalashnikov K.N., Morev M.V., Kalachikova O.N., Kondakova N.A. Zdorov'e izdravookhranenie : ucheb.posobie [Health and Health Care : Textbook]. Vologda: ISERT RAN, 2014. 154 p.

10. Izmeneniya v otraslyakh sotsial'noi sfery, napravlennye na povyshenie effektivnosti obrazovaniya i nauki : plan meropriyatii ("dorozhnaya karta"): utverzhden rasporyazheniem Pravitel'stva Rossiiskoi Federatsii ot 30 dekabrya 2012 g. № 2620-r [Changes in the Social Sphere Aimed at Improving the Efficiency of Education and Science : the Action Plan (Road Map): Approved by the Decree of the Government of the Russian Federation of December 30, 2012 No. 2620-r]. Konsul'tantPlyus [ConsultantPlus].

11. Informatsiya o vypolnenii plana meropriyatii ("dorozhnoi karty") za 1 polugodie 2014 goda [Information on the implementation of the Action Plan (Road Map) for the 1st Half of 2014]. Available at: http://depobr.gov35.ru/

12. Kalachikova O.N., Shabunova A.A. Reproduktivnoe povedenie kak faktor vosproiz-vodstva naseleniya: tendentsii i perspektivy : monografiya [Reproductive Behavior as a Factor in the Reproduction of Population: Trends and Prospects : Monograph]. Vologda : ISERT RAN, 2015. 172 p.

13. Markelov R. Sbory ushli v nulevku [Fees Went to Zero]. Available at: http://www.rg.ru/2015/05/05/detsad.html

14. Leonidova G.V. Doshkol'noe obrazovanie v Rossii: obespechennost' i dostupnost' [Pre-school Education in Russia: Security and Accessibility]. Problemy razvitiya territorii [Problems of Territory's Development], Vologda: ISERT RAN, 2015, vol. 79, no. 5, pp. 7 - 20.

15. Ob obrazovanii v Rossiiskoi Federatsii : Federal'nyi zakon ot 29 dekabrya 2012 g. № 273-FZ [On Education in the Russian Federation : Federal Law of December 29, 2012 No. 273-FZ]. Konsul'tantPlyus [ConsultantPlus].

16. Ob utverzhdenii plana meropriyatii («”rozhnoi karty”) Izmeneniya, napravlennye na povyshenie effektivnosti obrazovaniya 2013-2018 gody : postanovlenie Pravitel'stva Vologodskoi oblasti ot 25fevralya 2013 g. № 201: v red. postanovlenii Pravitel'stva Vologodskoi oblasti ot 25.04.2013 g. № 452, ot 05.08.2013 g. № 795) [On Approval of the Action Plan (Roadmap) Aimed at Improving the Efficiency of Education 2013-2018 : Vologda Oblast Government Decree of February 25, 2013 No. 201: in Ed. Decrees of the Vologda Oblast Government of April 25, 2013, No. 452, of August 5, 2013, No. 795]. Konsul'tantPlyus [ConsultantPlus].

17. Ob utverzhdenii SanPiN 2.4.1. 31.47-13 Sanitarno-epidemiologicheskie trebovaniya k doshkol'nym gruppam, razmeshchennym v pomeshcheniyakh zhilogo fonda : postanovlenie Glavnogo sanitarnogo vracha Rossiiskoi Federatsii ot 19 dekabrya 2013 g. № 68: zaregistrirovano v Minyuste Rossii 03.02.2014 g. № 31209 [On Approval of SanPiN 2.4.1. 31.47-13 Sanitary and Epidemiological Requirements for Preschool Groups, Hosted in the Premises of the Housing Stock: Decree of the Chief Sanitary Doctor of the Russian Federation of December 19, 2013 No. 68: Registered in the Ministry of Justice of Russia of February 3, 2014, No. 31209]. Konsul'tantPlyus [ConsultantPlus].

18. O nekommercheskikh organizatsiyakh : Federal'nyi zakon ot 12 yanvarya $1996 \mathrm{~g}$. № 7-FZ [On Non-Profit Organizations : Federal Law of January, 12, 1996 No. 7]. Konsul'tantPlyus [ConsultantPlus].

19. Ob organizatsii provedeniya konkursnogo otbora sub"ektov Rossiiskoi Federatsii, byudzhetam kotorykh v 2013 godu predostavlyayutsya subsidii iz federal'nogo byudzheta na gosudarstvennuyu podderzhku malogo i srednego predprinimatel'stva sub"ektami Rossiiskoi Federatsii: Prikaz Minekonomrazvitiya Rossii ot 24 aprelya $2013 \mathrm{~g}$. № 220 [On Organization of the Conduct of Competitive Selection of RF Subjects, which Budgets in 2013 Get Subsidies from the Federal Budget for State Support of Small and Medium Entrepreneurship by Subjects of the Russian Federation: Order of the Ministry of Economic Development of April 24, 2013 No. 220]. Konsul'tantPlyus [ConsultantPlus].

20. Poslanie Prezidenta RF Federal'nomu Sobraniyu 4 dekabrya $2014 \mathrm{~g}$. [Address of the President of the Russian Federation to the Federal Assembly December 4, 2014]. Available at: http://kremlin.ru

21. Savinskaya O.B. Chastnyi detskii sad v Rossii: obydennye praktiki i perspektivy razvitiya [Private Kindergarten in Russia: Routine Practices and Development Prospects]. Sotsiologicheskie issledovaniya [Sociological Studies], 2014, no.11, pp. 83-90. 
22. Seliverstova I.V. Dostupnost' doshkol'nogo obrazovaniya: vliyanie territorial'nogo faktora [Availability of Pre-School Education: Impact of Territorial Factor]. Available at: http://elochka28chap.ucoz.ru/publ/dostupnost_ doshkolnogo_obrazovanija/1-1-0-4 (accessed June 20, 2015).

23. Sistemy protivopozharnoi zashchity. Ogranichenie rasprostraneniya pozhara na ob"ektakh zashchity. Trebovaniya k ob" ektno-planirovochnym i konstruktivnym resheniyam : svod pravil SP $4.13130 .2013 \mathrm{~g}$. : utverzhden prikazom MChS Rossii ot 24 aprelya 2013 g. № 288 [Fire Protection System. Limiting the Spread of Fire on Protection Objects. Requirements of Object-Planning and Constructive Solutions : Set of Rules SR 4.13130.2013 : Approved by Order of the MES of Russia of April 24, 2013 No. 288]. Konsul'tantPlyus [ConsultantPlus].

24. Shabunova A.A., Rossoshanskii A.I. Uroven' zhizni naseleniya kak indikator modernizatsionnykh protsessov [Level of Living of the Population as an Indicator of Modernization Processes]. V mire nauchnykh otkrytii [In the World of Scientific Discoveries], 2013, no. 12, pp. 127-150.

\section{Cited Works}

1. Aleksandrova O.A., Nenakhova Yu.S. Changes in Preschool Education: where the Right Direction Russia is Going To? Population, 2015, no. 1, pp. 95-105.

2. Ballaeva E.A. Problems of Development of Alternative Forms of Preschool Education. Population, 2013, no. 1, pp. 64-73.

3. Speech of the Minister of Education and Science of the Russian Federation Dmitry Livanov at the 1st All-Russian Congress of Workers of Preschool Education. Available at: http://minobrnauki.rf/

4. Gadzhieva L.A. About Using the Private Sector's Possibilities to Solve the Problem of Availability of Preschool Education. Public Administration Issues, 2012, no. 4, pp. 169-176.

5. State Report on the Situation of Children and Families with Children in the Russian Federation in 2013. Available at: http://www.rosmintrud.ru/.../Doklad_o_polozhenii_detej_za_2013_god.doc

6. Preschool Institutions in the Vologda Oblast in 2004-2008: Statistics Digest. Territorial Body of the Federal State Statistic Service in the Vologda Oblast. Vologda, 2009. 42 p.

7. Preschool Institutions in the Vologda Oblast in 2010-2014: Statistics Digest. Territorial Body of the Federal State Statistic Service in the Vologda Oblast. Vologda, 2015. 63 p.

8. Housing Code of the Russian Federation : Federal Law of December 29, 2004 No. 188-FZ. ConsultantPlus.

9. Shabunova A.A., Kalashnikov K.N., Morev M.V., Kalachikova O.N., Kondakova N.A. Health and Health Care : Textbook. Vologda: ISERT RAN, 2014. 154 p.

10. Changes in the Social Sphere Aimed at Improving the Efficiency of Education and Science : the Action Plan (Road Map): Approved by the Decree of the Government of the Russian Federation of December 30, 2012 No. 2620-r. ConsultantPlus.

11. Information on the implementation of the Action Plan (Road Map) for the 1st Half of 2014. Available at: http:// depobr.gov35.ru/

12. Kalachikova O.N., Shabunova A.A. Reproductive Behavior as a Factor in the Reproduction of Population: Trends and Prospects : Monograph. Vologda : ISERT RAN, 2015. 172 p.

13. Markelov R. Fees Went to Zero. Available at: http://www.rg.ru/2015/05/05/detsad.html

14. Leonidova G.V. Pre-school Education in Russia: Security and Accessibility. Problems of Territory's Development, Vologda: ISERT RAN, 2015, vol. 79, no. 5, pp. 7-20.

15. On Education in the Russian Federation : Federal Law of December 29, 2012 No. 273-FZ. ConsultantPlus.

16. On Approval of the Action Plan (Roadmap) Aimed at Improving the Efficiency of Education 2013-2018 : Vologda Oblast Government Decree of February 25, 2013 No. 201: in Ed. Decrees of the Vologda Oblast Government of April 25, 2013, No. 452, of August 5, 2013, No. 795. ConsultantPlus. 
17. On Approval of SanPiN 2.4.1. 31.47-13 Sanitary and Epidemiological Requirements for Preschool Groups, Hosted in the Premises of the Housing Stock: Decree of the Chief Sanitary Doctor of the Russian Federation of December 19, 2013 No. 68: Registered in the Ministry of Justice of Russia of February 3, 2014, No. 31209. ConsultantPlus.

18. On Non-Profit Organizations : Federal Law of January, 12, 1996 No. 7. ConsultantPlus.

19. On Organization of the Conduct of Competitive Selection of RF Subjects, which Budgets in 2013 Get Subsidies from the Federal Budget for State Support of Small and Medium Entrepreneurship by Subjects of the Russian Federation: Order of the Ministry of Economic Development of April 24, 2013 No. 220. ConsultantPlus.

20. Address of the President of the Russian Federation to the Federal Assembly December 4, 2014. Available at: http:// kremlin.ru

21. Savinskaya O.B. Private Kindergarten in Russia: Routine Practices and Development Prospects. Sociological Studies, 2014, no.11, pp. 83-90.

22. Seliverstova I.V. Availability of Pre-School Education: Impact of Territorial Factor. Available at: http:// elochka28chap.ucoz.ru/publ/dostupnost_doshkolnogo_obrazovanija/1-1-0-4 (accessed June 20, 2015).

23. Fire Protection System. Limiting the Spread of Fire on Protection Objects. Requirements of Object-Planning and Constructive Solutions : Set of Rules SR 4.13130.2013 : Approved by Order of the MES of Russia of April 24, 2013 No. 288. ConsultantPlus.

24. Shabunova A.A., Rossoshanskii A.I. Level of Living of the Population as an Indicator of Modernization Processes. In the World of Scientific Discoveries, 2013, no. 12, pp. 127-150.

\section{Information about the Authors}

Galina Valentinovna Leonidova - Ph.D. in Economics, Associate Professor, Institute of SocioEconomic Development of Territories of RAS (56A, Gorky Street, Vologda, 160014, Russian Federation, galinaleonidova@mail.ru)

Irina Ivanovna Svirelkina - Secondary School No. 14, Vologda (32A, Dalnaya Street, Vologda, 160024, Russian Federation, svirelkina@mail.ru) 